EPiC Series in Language and Linguistics
Volume 3, 2018, Pages 1-11
LSP in Multi-disciplinary contexts of
Teaching and Research. Papers from the
16th International AELFE Conference

\title{
Connecting language students internationally in an era of heightened nationalism
}

\author{
Bruce Maylath \\ North Dakota State University, Department of English, P.O. Box 6050, Fargo, ND, 58108, USA
}

\begin{abstract}
Since the 1999-2000 academic year, the teaching network known as the Trans-Atlantic \& Pacific Project (TAPP) has internationally connected teachers and students in writing classes with students in translation studies and/or usability classes at nearly 30 universities in 15 countries on 4 continents. The network began forming as globalization knit nations closer together and as communication technologies, beginning with e-mail, began to become commonly available (Maylath, Vandepitte, \& Mousten, 2008). Now, however, the world seems to be entering an era that runs counter to globalization, as nationalists in many countries attempt to retract from international collaborations and connections. Despite that, students in language professions must learn how to collaborate internationally and across languages, cultures, and international borders. Despite a backlash to globalism that might threaten other international collaboration efforts and arrangements, the TAPP persists and grows because it is loose, lithe, and limber. It operates with nearly complete teacher autonomy, not relying on institutional agreements or fundingnot even grants (Maylath et al., 2013; Lisaité et al. 2016). This plenary address describes how the TAPP is able to function in this way and to continue to add partners in ever more countries. It also depicts how TAPP collaborations raise audience awareness, intercultural aptitude, language sensitivity, and writing effectiveness for both undergraduate and graduate students. Moreover, it demonstrates how international collaboration boosts recruitment, bolsters retention and engagement, and leads to job-placements at all levels, including the doctoral.
\end{abstract}

Keywords: globalization; nationalism; international collaboration

A. Curado (ed.), AELFE2017 (EPiC Series in Language and Linguistics, vol. 3), pp. 1-11 


\section{Introduction}

After more than 17 years of phenomenal growth, Trans-Atlantic \& Pacific Project (TAPP) collaborations have taken place at nearly 30 universities in 15 countries on four continents: Africa, Asia, Europe, and North America. During that time, scores of instructors have worked together to connect thousands and thousands of students. In so doing, they have exposed their students to a wide diversity of languages, cultures, and ethnicities. The realism of international collaborative projects has given students a much more acute sense of audience members and how they can differ. It has also given them crucial insights into the functioning of cross-cultural virtual teams, now so common in the global workplace.

\section{The idea of international collaboration takes root}

It's important to hear the early stories of the TAPP. Let's begin with how the first pairing of a writing class and a translation class took place. Already in the mid-1990s, when I was a new assistant professor at the University of Memphis, I was teaching students in technical writing courses how to prepare texts for translation. By 1997, I had published an article in the Journal of Business \& Technical Writing about what to cover in this way with students (Maylath, 1997). With many stories in the news about increases in global trade, students were interested in what I was teaching them, but many asked me, "Am I getting it right? Is this what translators really want?" Although I could pass along to them what translators whom I had interviewed had told me, I realized that my answering them was not the same as a translator's telling them.

In the summer of 1997, Sonia Vandepitte was finishing a year as a visiting scholar at the Massachusetts Institute of Technology (MIT). As Sonia and I had long known each other from the time when we were both studying Norwegian language and literature at the University of Oslo, I invited Sonia and her husband and their then-young daughters to fly to my home in St. Paul, Minnesota, so that they could experience the American heartland. During their visit, I asked Sonia what she expected to do when she and her family returned home to Belgium. She said that she had lined up a position teaching English-to-Dutch translation at the Mercator College of Translation \& Interpretation, in Ghent. I asked her what she expected to teach. One course was introductory translation.

I told her about the technical writing project that I had been assigning students: writing a set of instructions on a topic for which they considered themselves expert, testing the instructions to determine their usability, then revising the instructions and preparing them for translation. Sonia mentioned that instructions were a genre that she intended to have her introductory students translate. I asked her what she was planning to use as source texts. To that point, she had in mind asking students to find printed instructions that had accompanied a product that they had at home and to translate those. Hm. "Would you consider having your students translate instructions that my student wrote?" I asked her. "That might work," she replied. We talked over the pros and cons that day. 


\section{The revolution in communication technologies}

It would be a while, though, before the pieces fell into place. In 1998, I accepted a new position at the University of Wisconsin - Stout, about an hour's drive east of St. Paul. Each of us had to get our feet on the ground at our new institutions. Thus, in the 1999-2000 academic year, we were able to work out an initial design. The first challenge - and this has been one of the biggest challenges whenever TAPP instructors start planning-was to examine our institutions' calendars and make our assignments dovetail with each other. Fortunately, the semesters in Wisconsin and Belgium usually start within a week of each other. However, to give my students sufficient time to write, then Sonia's students sufficient time to translate, I had to move my writing assignment earlier in the semester than it had typically occurred, while she had to move her translation assignment later.

With the initial challenge overcome rather easily, we moved on to the next challenge: communication technologies. No matter how clever an idea it might be to have writing students and translation students collaborate on a text while on different sides of an ocean, it could not realistically be implemented without technology that communicated texts and queries in rapid time, that is to say, in a fashion that could elicit a response and continuing dialogue within 24 hours. Some of the younger people in this room may not realize how long overseas dialogue typically took before the late 1990s. When I was a student at the University of Oslo and wanted to ask my parents a question, I could send a letter or aerogramme by airmail, and it would take at least five days to reach the U.S.- - sometimes even seven or more. If I mailed the aerogramme on a Monday and my parents received it by Saturday, they could then write a response on Sunday, and mail it the next day, which was exactly a week after I had mailed my correspondence to them, I might receive it by the following Saturday. Often it was the following Monday, thus taking a query and reply a full two weeks. Remember, this was before texting, before Facebook or WhatsApp or Instagram. It was also before Skype. I lived in Norway twice during the 1970s and 80s, and during those periods overseas I talked with my parents by telephone perhaps three times altogether. International calls were simply too expensive to place often.

By the late 1980s, Federal Express, now known as FedEx, was delivering packages, including documents, overnight, but at a price that was exorbitant for an international, collaborative student project. By the early 1990s, facsimile machines, or what we now shorten to "fax machines," had brought the price of rapid communication down considerably, but still the price would have been exorbitant for an international student project, as the faxes would have had to travel through international phone lines at international rates. By the mid-1990s, e-mail was beginning to spread to workplaces, including universities. However, even in the autumn of 1999, we weren't sure that it would be accessible to our students. While faculty members and students at the University of Wisconsin's Stout campus were being assigned e-mail addresses by then, and while the faculty at Mercator College in Belgium were as well, the students at Mercator were not. Using her faculty e-mail account, Sonia wrote me in late 1999 that this might pose a barrier to arranging the students in our classes into writer-translator pairs. She knew that some students had their own private accounts, such as through Hotmail or Yahoo, but she wasn't sure how many. She decided to poll her students on the first day of class. 
The next day she e-mailed me the results of her poll: All but three students already had their own private e-mail accounts, which they were happy to use for the project. For the three who did not, she asked those who did to show those who did not how to register for a free account. This was our first lesson: international student collaborations can work without grants or student fees. Additionally, they can operate effectively without institutional agreements or administrative structure. Keep these two in mind as we think about how international collaboration can be sustained in an era of increased nationalism and authoritarianism in reaction to globalization: 1) no reliance on money, 2) no reliance on institutions or administrators. Both are keys not only to the TAPP's quick growth but also its sustainability.

With all students now equipped with e-mail, even if not provided by their institution, the project was off and running. In hindsight, we can see that the secret to the success that followed was not just the idea of putting writer and translator in touch with each other. Equally important was being able to gain access to new communication technologies-for free. (If you're not familiar with Elisabet Arnó's book, Information Technology in Languages for Specific Purposes, co-edited with Antonia Soler Cervera and Carmen Rueda Ramos, I urge you to take a look at it. Already in 2006, they were observing that "One of the most apparent advantages of network-based communication is the possibility of carrying out distributed projects both for learners and teachers" [p. 250] They noted further that "Often this collaboration takes places among LSP teachers with similar need and interests, who, precisely due to their specific profile, need to establish connections with partners from different geographical settings" [p. 251].) By about a year later, in 2001, Mercator College began providing e-mail addresses to all its students, in part because of the evidence that Sonia was able to provide the college's administrators revealing the usefulness of e-mail to students' learning through international collaborations like ours. At first, we didn't have a name for the project. After a few weeks, however, Sonia e-mailed me that, when she was talking about the project with her class, she had been referring to it as "The Trans-Atlantic Project." Thus, the acronym "TAP" was born. Many years later, when universities in China and Siberian Russia were added, the name would expand to "The Trans-Atlantic \& Pacific Project," but still remain the "TAPP."

\section{Realistic discoveries of lexical differences and dialect variation}

What we were only dimly aware of at the time was that the launch of the TAP could not have been better timed. We were probably some of the very first to link classes overseas by e-mail. Before that, airmail, overnight jet deliver, and faxes would have been prohibitively expensive for a project like ours, particularly at two highly intensive teaching institutions, to use the Carnegie descriptions, where research grants were seldom seen.

Throughout the first year, we were seeing benefits to students that we hadn't even anticipated, in both linguistics and culture (Humbley, Maylath, Mousten, Vandepitte, \& Veisblat, 2005; Maylath, Vandepitte, \& Mousten, 2008; Mousten, Vandepitte, \& Maylath, 2008). I'll start with a linguistic example from the very first semester. It's a story that I tell students whenever they are about to embark on a TAPP collaboration, and a version of it is published in the international professional journal connexions (Sorensen, Hammer, \& Maylath, 2015). It

illustrates how beneficial are discussions of a text's meanings as translation students strive to render the meaning of the source language accurately in the target language. 
In the spring semester of 2000 , one of my students, named Steven, wrote instructions that he titled "Cleaning Your VCR." The meaning of "VCR" may not be known to younger people today. The letters stand for "video cassette recorder." Last summer I read that the last one had been manufactured. That gives you an idea of how long the TAPP has been around. Steve was paired with a student in Ghent named Joke. When Joke read through Steve's text, she had some questions about terms. Translators who work through translation agencies often are not allowed to contact the writers of their source texts. However, TAPP collaborations put translators in direct contact with source text authors, so Joke did just what Sonia had encouraged her class to do. She e-mailed Steve.

The first question in her e-mail was "What is a "foam swab"?" Now, "Foam swab" is hardly a common phrase in English, but it's one that native English speakers easily figure out, even when they're hearing it for the first time. However, for a non-native speaker viewing it for the first time and having to look up the words "foam" and "swab" individually, the two words taken together can be confounding. The first meaning of "foam" is froth or scum or bubbles on top of water. "Swab" is a kind of mop. You can imagine Joke thinking, Does a VCR user need to mop water and froth off a VCR when cleaning it?

Even more instructive for our purposes was Joke's second question: "What do you mean with a "wall outlet'?" Although the Steve had gone through his text with a fine-toothed comb and included a glossary of technical terms, he had not considered "wall outlet" to be a term that required definition or clarification. Through their subsequent email dialogue, both Steve and Joke discovered why a simple, everyday American phrase turned out to be so confusing initially:

1. If Steve had included the word "electrical," the meaning of the phrase would have been transparent. With this critical word assumed and thus invisible, the phrase on its surface appeared to refer to a window or door opening in a wall.

2. "Outlet" to mean an electrical receptacle is peculiar to American English. Living just across the North Sea from Britain, Sonia's translation students in Belgium had, naturally enough, been taught British English. The British say "socket." If Steve had written "wall socket"- a term found in American English as well—Joke would have understood.

3. Including the word "wall," but not "electrical," prompted further confusion, instead of clarity. When Joke read "wall outlet," what first entered her mind, Sonia told me later, was an automatic teller machine (ATM) - a cash dispenser. Because so many ATMs in Europe appear along the sidewalks in the outer walls of banks, Flemish speakers of Dutch are fond of uttering their idiom "go to the wall," when they wish to withdraw money from an ATM. Wondering why cleaning a videocassette recorder suddenly required cash, Joke decided that she had better ask Steve what he really meant by "wall outlet." (By the way, it wasn't until 10 years later, when Sonia and I and Patricia Minacori were running a workshop on the TAPP at the International Professional Communication Conference, meeting in the Netherlands that year, that we discovered that the Dutch idiom "to go to the wall" to get cash is peculiar to Flemish Dutch. When Sonia told the story that I just told you and said, "as we say in Dutch," audience members from the Netherlands responded with surprise, asking "You say what in Flanders?" Just as there are distinct dialect differences between American English and British English, there are as well between Flemish Dutch and Dutch Dutch.) 
Such serendipitous episodes, like this e-mail exchange between Joke and Steve, are the hallmark of TAPP collaborations. They can never be planned ahead of time or learned just from a textbook. Rather, they are the inevitable result of languages in contact. When the writing process includes the translation process, the meanings of a text and its ambiguities must be examined closely. More than any other readers, translators have to know exactly what their source-text writers mean to say; otherwise, they will introduce errors in the target text. The TAPP instructors of writing courses commonly point out that what their writing students learn best from their translation partners is that the texts that they write are not nearly as clear and unambiguous as they think that they are. Thus, we learned our second lesson: TAPP collaborations are strikingly realistic. They engender learning experiences that can never be covered adequately in a textbook or encountered when a student works in isolation (Mousten, Maylath, Vandepitte, \& Humbley, 2010).

\section{Variety among texts assigned}

Since that time, instructors across the TAPP network have assigned multiple types of texts to write and translate. Examples include creative writing and literary translation (Vandepitte, 2016), humanities essays and social science reports (Hammer \& Maylath, 2014; Steinmann, Saduov, \& Maylath, 2016), and a variety of genres in what Americans call first-year writing or freshman-writing courses (Verzella \& Tommaso, 2014; Verzella \& Mara, 2015; LewandowskaTomaszczyk \& Slomski, 2016). Most such projects are bilateral, pairing one class of writers with one class of translators. However, since 2010, several members of the TAPP network have experimented every other year with multilateral projects (Maylath, Vandepitte, Minacori, Isohella, Mousten, \& Humbley, 2013; Maylath, King, \& Arnó Macià, 2013; Arnó Macià et al., 2014; Vandepitte, Mousten, Maylath, Isohella, Musacchio, \& Palumbo, 2015; Vandepitte, Maylath, Mousten, Isohella, \& Minacori, 2016). In these projects, students from Spain and the U.S. have co-authored instructions, conducted usability tests on them with students from Finland, and partnered with translation studies classes in Belgium, France, and Italy simultaneously. The U.S. students in these classes have also partnered with the same students in Belgium and Italy, plus students in either Denmark or Greece, to edit and review news articles translated from Dutch, Italian, and Danish or Greek into English.

\section{Realistic discoveries of cultural differences}

Another benefit to students became apparent as soon as they began introducing themselves to their partners. They learned far more about each other's cultures than we could ever have anticipated or planned (Mousten, Humbley, Maylath, \& Vandepitte, 2012). They did so in their dialogues with each other by pursuing their own curiosity about each other. We saw this first, again in March of the year 2000, when one of my students, named Wanda, received an introductory reply when she e-mailed her translation partner, Sonia's student named Gert. The next morning, Wanda asked me after class, "How is my partner able to read my text? He told me that he's legally blind." I told her, "Why don't you send him another e-mail message and ask him?" It turned out that Gert was just as interested in the fact that Wanda had told him that she was not only the mother of three children but also that she and her husband frequently fostered young adults who had escaped abusive households. For the rest of the semester, Wanda and Gert carried on an extensive dialogue by e-mail, asking each other about how they lived their lives and how their cultures were similar or different. When Wanda first learned from Gert how he used technology for the vision-impaired to decipher her text in English, I asked her to report 
what she had learned to the rest of her class. I also encouraged the rest of the class to initiate dialogues with their partners about differences in cultures, starting with holidays. My students were often surprised that Belgians did not necessarily have the same holidays that Americans have. (This probably sounds obvious to us in this room, but most Americans live astoundingly insular lives, as if the United States were a world unto itself. That's one of the reasons why TAPP collaborations are so valuable to their learning.) Going far beyond what was expected, many partners began sending each other descriptions about their lives and cultures. They were often prompted by seemingly banal exchanges of logistical information, such as "I may not answer my email for a few days while I'm on spring break," leading to questions such as "What do American students do on their holidays?" Thus, emerged our third lesson: simply by putting partners from different cultures in touch with each other, TAPP collaborations fostered much more learning about cultural similarities and differences than could be covered in a textbook or in course lectures (Hammer \& Maylath, 2014; Verzella \& Mara, 2015; Lisaité et al., 2016; Steinmann, Saduov \& Maylath, 2016). Simply allowing students to follow their own curiosity about each other was the key.

\section{The cult of monolingualism}

Now back to culture: As you're undoubtedly aware, the U.S. is currently experiencing the most tumultuous time that I've seen since the period 1967 through 1970. Last year's presidential election campaign is unlike any I've seen before. In many ways, it parallels what's happening in your countries, and it may lead to shocks, much as last year's Brexit referendum did in Britain. One of the reasons for to bring together scholars and teachers from different nations, languages, and cultures in one place this week is so that we can learn even more about each other's cultures and thus, when we go back to our teaching, we'll be better able to explain to our students the insights that we've gained into their partners' cultures. As we talk over meals and coffee breaks, I encourage you to pursue your curiosity and ask conference participants about the similarities and differences in their cultures. In particular, for those of you from Europe, I encourage you to ask the Americans in the room for help in understanding the distinct peculiarities of American culture. How has the US managed to remain United States?

Unfortunately, one contributing factor has been a cult of monolingualism. In Minnesota, as the US presidential primary campaign was beginning in late 2015, a woman in a restaurant in the Minneapolis suburb of Coon Rapids overhead a conversation among fellow diners at the next table. When she recognized that they were talking in a language other than English, she walked over to the woman whom she had last heard speaking and swung her beer mug into the speaker's face so hard that she inflicted severe wounds on the speaker. The speaker was Somali, and the language that she and the others at her table were speaking was Swahili, one of the most widely spoken languages in East Africa (Ibrahim, 2015). Fortunately, the incident was reported and vast numbers of Minnesotans were outraged that anyone in America could be assaulted and battered simply for exercising their right to free speech, whatever the language.

In America, it can take courage to stand up for the rights granted to you in the U.S. Constitution. Asma Jama responded to her batterer with courage. She was the Somali woman speaking Swahili with her family at that restaurant in Minnesota. When the woman from the next table shouted at her "when you're in America, you should speak English,"Asma Jama replied, "I'm home. I can speak English, but we choose to speak whatever language we want." In order to prevail, to speak your mother language, and to face down the hatred of Americans 
like the batterer in Coon Rapids, you need to know that their hatred is rooted in fear. Americans' English-Only attitude is closely tied to America's periodic waves of fears of immigrants, and if you've been listening to Donald Trump, you know that we are currently smack in the middle of one of those waves right now. It helps to know the history of those waves. They stem from a fear that immigrants are not loyal to the United States if they speak a language besides English. It is sharpened by the nation's long-standing official policies to exterminate all languages other than English, beginning with those native to America, like Dakota and Ojibwe and Mandan.

For much of the $20^{\text {th }}$ century, the US government promulgated official policies to exterminate all languages other than English, beginning with those native to America. At the same time that the U.S. military was using Native American languages to send secret codes, the U.S. Bureau of Indian Affairs was doing all it could to eliminate those languages (Winterman, 2014). The English-Only mindset was extended in 1917 to all other languages, especially German. The main reason that Americans don't learn languages besides English isn't really because they don't want to spend the money on teaching them. In actuality, it stems from fear of immigrants and suspicion that they are not loyal to the US if they speak a language besides English.

During the First World War, German speakers all over North America felt forced to abandon their language in favor of English. To put this in perspective, consider that, until 1917, a third of all the schools in Minnesota taught primarily in German - and this statistic does not include the ones that taught primarily in Norwegian or Polish (Rippley, 1981). The state government of Minnesota forced them quite suddenly to stop, just weeks after Congress declared war in 1917. German-Americans in the U.S. were fully aware of what had already happened just to the north in Canada, when that country was drawn into the war in 1914: German-Canadians were rounded up and placed in what we've come to call internment camps - although, during the First World War, they were called concentration camps. Both the U.S. and Canada would repeat this practice nearly three decades later during the Second World War-this time mainly with Japanese-Americans and Japanese-Canadians, although both countries did place hundreds of citizens of German and Italian descent in camps as well—something you rarely hear about today.

Many state legislatures banned instruction in any languages but English. In the early 1920s, the US Supreme Court overturned these laws, on the grounds that they violated the $1^{\text {st }}$ Amendment right to free speech. However, they did allow the regulation of language instruction. Very quickly following that ruling, many states banned outright the teaching any languages other than English before 9th grade (in the full knowledge that children in the prime learning years of language would not become fluent). The last I checked, Kansas still has that law in place.

The result is that the vast majority of Americans never gain competence in a language other than English (a premeditated and deliberate outcome of state legislators), they never hear or read ideas not expressed in or translated to English, and they never acknowledge that they're doing a power play when, say, at an international roundtable that I attended in Europe in 2015, they do not slow down, do not enunciate, do not check their idioms and culturally bound humor, but do try to dominate the conversation. The Trans-Atlantic \& Pacific Project is a small but crucial effort to try to overcome many American students' fear of other languages, other cultures, and, most importantly, the peoples of those languages and cultures. 


\section{The keys to the TAPP network's success}

So now you have a picture of how the TAPP began and how it quickly revealed that it could lead to large leaps in students' learning lessons in audience awareness, linguistic peculiarities, differing cultures, and also human commonalities. If we turn from history to the present, we see that the TAPP is flourishing because it follows a simple recipe: Pour in equal parts instructors, mix their students, and — voila — amazing learning happens. It flourishes as well because it is not hampered by institutional agreements, administrative bureaucracy, or the agendas of nonteachers, such as grant-funding agencies and university governing boards. What's more, it is not subject to budget cuts, such as those that the State of North Dakota is now imposing on its universities, as the oil boom has switched to an oil bust. Indeed, the funding that the TAPP has received has been mainly for many of us to travel to conferences, like this one, where we've made presentations and run workshops on the TAPP, its pedagogical approaches, and research on cross-cultural virtual teams that has emanated from it. These conferences have usually been ones that we would have attended and sought funding for anyway.

That said, clearly money can help you do some things that you can't do otherwise. Three years ago several of us, led by Elisabet Arnó, assembled a proposal for an ERASMUS+ grant, sponsored by the European Union. The amount requested was $€ 446,045$. It would have funded a series of controlled experiments using TAPP teaching approaches. Although we didn't get it, we did receive helpful feedback, enough to decide to try again, this time focusing on research that the EU wants to see results for. We also learned that we might have better chances if the lead university were not in Western Europe but in Eastern Europe. Thus, our effort is being led this time by Barbara Lewandowska-Tomaszczyk at the State University of Applied Sciences in Konin, Poland.

Even without grant funding, however, the number of research and scholarly publications that members of the TAPP network have produced about the TAPP is rather astonishing: nearly 20 articles and book chapters so far, with an anthology and more articles under development. So where is the TAPP headed in the future? Given the backlash against globalization and international collaboration and new era of nationalism and authoritarianism that the backlash seems to be ushering in, I feel compelled to note that, although the TAPP is in no way political, it is indirectly affected by the politics outside our classrooms, by shaping our students' attitudes, especially toward other languages, other cultures, and other peoples. As you hear exclamations about banning peoples of certain nationalities, certain cultures, or certain religions, as you hear ranting about those who don't speak a particular language or raving about building walls to keep them out, keep in mind that the TAPP is dedicated always to connecting students across languages, cultures, and nations. We transcend walls. As long as there's a free Internet, we will always arrange for our students to connect across any ocean, any mountain range, any national boundary, any time zone difference, and any language divide. Je n'ai pas peur. No tengo miedo. We are not afraid: We are the Trans-Atlantic \& Pacific Project. We are international LSP professionals. 


\section{Acknowledgements}

This plenary address would not be possible without the dozens of teachers and thousands of students who have participated in TAPP collaborations. This address is dedicated to the memory of two TAPP teachers who have now passed away: Lis Brøgger, of Aarhus University, Denmark, and Daniel Riordan, of the University of Wisconsin-Stout, USA.

\section{References}

Arnó Macià, E., Isohella, S., Maylath, B., Schell, S., Verzella, M., Minacori, P., Mousten, B., Musacchio, M. T., Palumbo, G., Vandepitte, S. (2014). Enhancing students' skills in technical writing and LSP translation through telecollaboration projects: Teaching students in seven nations to manage complexity in multilateral international collaboration. In G. Budin \& V. Lušicky Languages for Special Purposes in a Multilingual, Transcultural World. Proceedings of the 19th European Symposium on Languages for Special Purposes, 8-10 July 2013. Vienna, Austria. Retrieved

https://typo3.univie.ac.at/fileadmin/user_upload/k_1sp2013/LSP2013_Proceedings/06_TT/LSP2013_Arno_et_al.pdf

Arnó Macià, E., A. Soler Cervera, \& C. Rueda Ramos. (2006). Information Technology in LSP: Prospects on a Brave New World. In E. Arnó Macià, A. Soler Cervera, \& C. Rueda Ramos, (Eds.), Information technology in languages for specific purposes: Issues and prospects (pp. 247-261). New York: Springer. Educational Linguistics, vol. 7.

Hammer, S., \& Maylath, B. (2014). Real time and social media in trans-Atlantic writing/translation and translation/editing projects. In M. Limbu \& B. Gurung (Eds.), Emerging pedagogies in the networked knowledge society: Practices integrating social media and globalization (pp. 144-161). Hershey, PA: IGI-Global.

Humbley, J., Maylath, B., Mousten, B., Vandepitte, S., \& Veisblat, L. (2005). Learning localization through transAtlantic collaboration. In G. F. Hayhoe (Ed.), Proceedings of the IEEE International Professional Communication Conference, 10-13 July 2005, U of Limerick, Ireland (pp. 578-595). New York: IEEE.

Ibrahim, M. (2015, Nov. 6). Applebee's attack victim: "I'm scared for my life." Minnesota Public Radio News. Retrieved from http://www.mprnews.org/story/2015/11/06/applebees-attack-victim

Lewandowska-Tomaszczyk, B., \& H. A. Slomski. (2016). Collaboration in language development between American and Polish university students. Konin Language Studies, 3, 305-329.

Lisaité, D., Vandepitte, S., Maylath, B., Mousten, B., Valdez, S., Castel-Branco, M., \& Minacori, P. (2016). Negotiating meaning at a distance: Peer feedback in electronic learning translation environments. In B. LewandowskaTomaszczyk \& Ł. Bogucki (Eds.), Translation and meaning (pp. 99-113). Frankfurt am Main: Peter Lang, Lódź Studies in Language, New Series, vol. 1.

Maylath, B., King, T., \& Arnó Macià, E. (2013). Linking engineering students in Spain and technical writing students in the US as coauthors: The challenge and outcomes of subject-matter experts and language specialists collaborating internationally. connexions: International Professional Communication Journal, 1(2), 150-185.

Maylath, B. (1997). Writing globally: Teaching the technical writing student to prepare documents for translation. Journal of Business and Technical Communication, 11, 339-52.

Maylath, B., Vandepitte, S., Minacori, P., Isohella, S., Mousten, B., \& Humbley, J. (2013). Managing complexity: A technical communication/translation case study in multilateral international collaboration. Technical Communication Quarterly, 22, 67-84.

Maylath, B., Vandepitte, S., \& Mousten, B. (2008). Growing grassroots partnerships: Trans-Atlantic collaboration between American instructors and students of technical writing and European instructors and students of translation. In D. Stärke-Meyerring \& M. Wilson (Eds.), Designing global learning environments: Visionary partnerships, policies, and pedagogies (pp. 52-66). Rotterdam: Sense Publishers.

Mousten, B., Humbley, J., Maylath, B., \& Vandepitte, S. (2012). Communicating pragmatics about content and culture in virtually mediated educational environments. In K. St. Amant \& S. Kelsey (Eds.), Computer-mediated communication across cultures: International interactions in online environments (312-327). Hershey, PA: IGI Global.

Mousten, B., Maylath, B., Vandepitte, S., \& Humbley, J. (2010). Learning localization through trans-Atlantic collaboration: Bridging the gap between professions. IEEE-Transactions on Professional Communication, 53, 401-411.

Mousten, B., Vandepitte, S., \& Maylath, B. (2008). Intercultural collaboration in the trans-Atlantic project: Pedagogical theories and practices in teaching procedural instructions across cultural contexts. In D. Stärke-Meyerring \& M. Wilson (Eds.), Designing global learning environments: Visionary partnerships, policies, and pedagogies (pp. 129-144). Rotterdam: Sense Publishers.

Rippley, L.V.J. (1981, Spring). Conflict in the classroom: Anti-Germanism in Minnesota school, 1917-19. Minnesota History, 47, 170-183. Retrieved from http://collections.mnhs.org/mnhistorymagazine/articles/47/v47i05p170-183.pdf

Sorensen, K., Hammer, S., \& Maylath, B. (2015). Synchronous and asynchronous online international collaboration: The Trans-Atlantic \& Pacific Project. connexions: International Professional Communication Journal, 3(1), 153-177. 
Steinmann, H., Saduov, R., \& Maylath, B. (2016). Learning across borders: A teaching case connecting writing students internationally. Konin Language Studies, 3, 271-287.

Vandepitte, S. (2016). Collaboration in translation practices in Dutch-speaking areas. Konin Language Studies, 3, 289-304.

Vandepitte, S., Maylath, B., Mousten, B., Isohella, S., \& Minacori, P. (2016). Multilateral collaboration between technical communicators and translators: A case study of new technologies and processes." The Journal of Specialised Translation, 26, 3-19.

Vandepitte, S., Mousten, B., Maylath, B., Isohella, S., Musacchio, M. T., \& Palumbo, G. (2015). Translation competence: Research data in multilateral and interprofessional collaborative learning. In Y. Cui \& W. Zhao (Eds.), Handbook of research on teaching methods in language translation and interpretation (pp. 137-159). Hershey, PA: IGIGlobal.

Verzella, M., \& Mara, A. (2015). Translocal pragmatics: Operationalizing postnational heuristics to locate salient cultural overlap. Rhetoric, Professional Communication and Globalization, 7(1), 12-28.

Verzella, M., \& Tommaso, L. (2014). Learning to write for an international audience through cross-cultural collaboration and text-negotiation. Changing English: Studies in Culture and Education, 21, 310-321.

Winterman, D. (2014, May 19). World War I: The original code talkers. BBC News Magazine. Retrieved from http://www.bbc.com/news/magazine-26963624 